\title{
Dried Siam Weed (Chromolaena odorota) as Rice Weevils' (Sitophilus oryza) Eradicant
}

\author{
Liwayway H. Acero
}

\begin{abstract}
- this research was undertaken to tap the beneficial use of Dried Leaves of Siam weed to eradicate rice weevils in storage area. It also seeks to find out what best proportion in weight of dried Siam weed leaves and rice grain would get rid the rice weevils. Experimental research method with five treatments was utilized. Gathered data was analyzed using ANOVA single factorial. Findings of the study revealed that highest percentage of mortality after seven days, was obtained from treatment 5 with 40 percent $(20$ grams dried Siam weed: 50 grams of rice grain) dried leaves of Siam weed. Based on this study rice farmers and rice traders could use dried leaves of Siam weed to eradicate rice weevils in their storage area, to demand for higher price for good quality rice.
\end{abstract}

Index Terms-Chromolaena odorata leaves.

\section{INTRODUCTION}

Mans' quest for food means survival. To attain good health, quality food should be provided. In Asia, one of the main energy sources is rice (Oryza sativa). In the Philippines, rice is the main energy source fro Filipinos. Being a tropical country, which favors the existence of insect pests, rice in storage areas suffer from decrease in quality. Insect pest like weevil destroys its grain. The rice weevil, Sitophilus oryzae, is one of the most destructive pests of stored cereals. Weevil adults attack whole grains, and larvae cryptically feed and develop within grains. It has chewing mouthparts at the end of their snouts or prolonged heads, and is about 1/8- to 3/16-inch long, depending on the size of the grain kernel. The adult rice weevil is a dull reddish-brown with round or irregularly shaped pits on the thorax and four light spots on the wing covers. Adult rice weevils live for four to five months and each female lays 300 to 400 eggs during this period. The female uses her strong mandibles to chew a hole in the grain kernel where she deposits a single egg and seals the hole with a gelatinous fluid. Damage to grain caused by this weevil includes reductions in nutritional value, germination, weight, and commercial value [1]. There are many sources of indigenous plants that contain phytochemicals that could serve as repellent or may kill insects. One of these is Chromolaena odorata. C. odorata is viewed as a major agricultural sustainability problem in many tropical countries. It was recognized as the most problematic weed in coconut plantations in Sri Lanka as early as 1944, and became a problem in rubber, palm oil, tea, coffee, cashew, teak and other plantation crops in Asia [2]. Although surveys has

Manuscript received January 4, 2014; revised March 6, 2014.

Liwayway H. Acero is with the Department of Natural Sciences, San Beda College, Manila Philippines (e-mail: lilyacero1@yahoo.com). identified that many farmers believe botanicals are cheap, available and thought to be safer than conventional pesticides, there is also evidence that a lack of understanding prevents their widespread uptake [3]. In Africa, Chromolaena odorata (Siam weed) is sometimes mixed with stored grain to control common storage pests, such as the Larger Grain Borer (Prostephanus truncatus) and maize weevil (Sitophilus zeamais), but the opinion of farmers regarding its efficacy has been shown to vary [4]. A study on the phytochemical screening of Siam weed revealed the presence of alkaloids, cyanogenic glycosides, flavonoids (aurone, chalcone, flavone and flavonol), phytates saponins and tannins. The anti-nutrients composition includes cyanogenic glycosides $(0.05 \% \mathrm{WW}$ and $0.13 \% \mathrm{DW})$, phytates $(0.22 \% \mathrm{WW}$ and $0.54 \% \mathrm{DW})$, saponins $(0.80 \% \mathrm{WW}$ and $1.98 \% \mathrm{DW})$ and tannins $(0.15 \% \mathrm{WW}$ and $0.37 \% \mathrm{DW})$ [5]. There are a lot of studies that uses the essential oil of Siam weed as fumigants for insects, however the taste of grain is affected and the environmental hazard caused by fumigants is quite questionable. In the Philippines Siam weed is a highly invasive plant species which is poorly studied in spite of the fact that it is hard to eradicate, a nuisance in plantations, and known to harm farm animals and decimate forage and native plant species [6]. Thus, this study focuses on the use of dried Chromolaena odorata leaves to eliminate rice weevil in storage areas in order to tap the beneficial use of this weed.

The objective of this study is to determine what proportion in weight does dried Chromolaena odorota leaves could eliminate rice weevil in storage areas of rice. Result of this study could serve best the rural farmers and rice traders on how to maintain good quality of rice to demand higher price for their product. Ultimate consumer could still enjoy eating quality rice even its not harvest season.

\section{MATERIALS AND METHODS}

This study made use of experimental research method with five treatments and five samples per treatment. The controlled variables such as, the same number of live weevils per sample (10), same weight of rice grains (50 grams), same size of the containers, were used to avoid bias in study. The experimental variable which is the weight of dried Chromolaena leaves varied per treatment.

\section{A. Materials}

Dried Chromolaena odorata leaves, rice grain, live rice weevils, digital balance, plastic containers with tight seal, scotch tape, record book, magnifying glass and camera were prepared. 


\section{B. Preparation of Dried Chromolaena Odorata Leaves}

Leaves of Siam weed (Fig. 1a) were gathered and sundried for five days. It was packed in plastic container to minimize moisture accumulation (Fig. 1b).

\section{Weighing of the Materials Used}

Rice grain from rice trader was purchased. Sealed plastic containers, scotch tape were also prepared. To attain accuracy in the weight of rice grains and dried Siam weed, a digital balance was used to (Fig. 2). The treatments are as follows;

Treatment 1 (control), 50 grams rice grains, $0 \%$ dried Chromolaena odorata leaves. Treatment 2, (10\% dried Chromolaena odorata), 50 grams rice grain, with 5 grams dried Chromolaena odorata leaves. Treatment 3, (20\% dried Chromolaena odorata), 50 grams rice grain, with 10 grams dried Chromolaena odorata leaves. Treatment 4, (30\% dried Chromolaena odorata leaves), 50 grams rice grain, with 15 grams dried Chromolaena odorata leaves, and treatment 5 (40\% dried Chromolaena odorata leaves) 50 grams rice grain with 20 grams dried Chromolaena odorata leaves.

\section{Incorporation of Live Rice Weevil and Packing of the Containers}

Live rice weevils were collected from the storage area of the rice trader. Each treatment has five sample containers and each sample container contained ten live rice weevils. All in all there were 25 containers used and 250 live rice weevils (Fig. 3a and 3b).

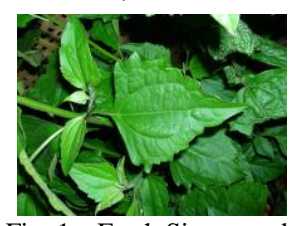

Fig. 1a. Fresh Siam weeds

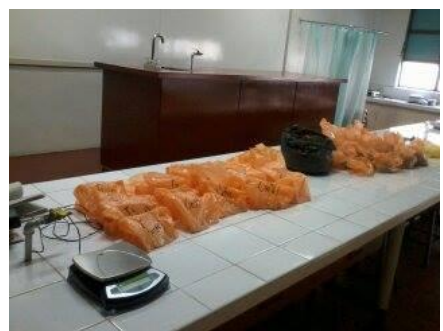

Fig. 2. Rice grain and dried Siam weed were weighed in the digital balance.

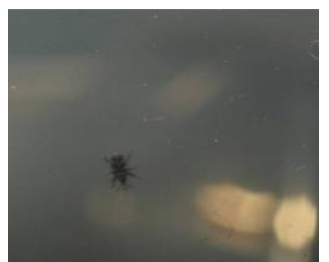

Fig. 3a. Rice weevil inside the container. Fig. 3b. Experimental containers.

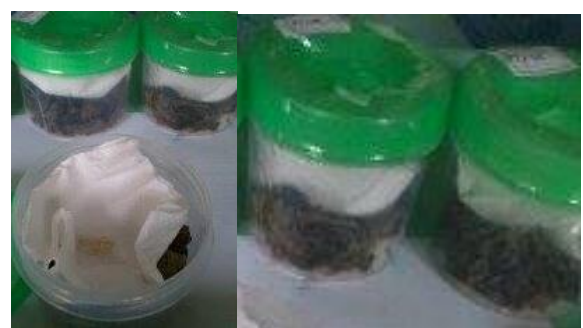

Fig. 4. Dried Siam weed packed as bedding materials in sealed containers.
Dried Chromolaena odorata leaves were placed in the bottom of the container as bedding material. Tissue paper was placed on top to hold the rice grains in placed. The container were closed properly and sealed with scotch tape to ensure that the weevils will stay in place (Fig. 4). Needle size holes $(1 / 10 \mathrm{~mm})$ were punctured on the cover of the containers to serve as aeration during the conduct of the study.

\section{E. Data Gathered}

The data gathered includes the number of rice weevils that survived after seven days. Mortality rate was also obtained and expressed in graph. After a week the containers were opened and the number of live rice weevils was counted per sample container. Likewise, rice weevils that did not survive were entered in the graph for mortality rate. Other observations also include the behavior (motility) of live weevils after seven days.

\section{RESULTS}

\section{A. Number of Rice Weevils per Sample, per Treatment on the Start of the Study}

Table I shows the number of live rice weevils per sample per treatment. To ensure uniformity and avoid bias on the controlled variables like the number of rice weevils, all samples per treatment contained ten live rice weevils obtained from the same source. The total live weevils per treatment, was fifty with a mean of ten. It means that all samples were treated equal on the start of the study.

TABLE I: NUMBER OF RICE WEEVILS PER SAMPLE, PER TREATMENT ON THE START OF THE STUDY

\begin{tabular}{llllllll}
\hline \hline Treatment/sample & 1 & 2 & 3 & 4 & 5 & Total & Mean \\
\hline 1 (control) & 10 & 10 & 10 & 10 & 10 & 50 & 10 \\
\hline $\begin{array}{l}2(10 \% \text { dried Siam } \\
\text { weed) }\end{array}$ & 10 & 10 & 10 & 10 & 10 & 50 & 10 \\
\hline $\begin{array}{l}3(20 \% \text { dried Siam } \\
\text { weed) }\end{array}$ & 10 & 10 & 10 & 10 & 10 & 50 & 10 \\
\hline $\begin{array}{l}4(30 \% \text { dried Siam } \\
\text { weed) }\end{array}$ & 10 & 10 & 10 & 10 & 10 & 50 & 10 \\
\hline $\begin{array}{l}5(40 \% \text { dried Siam } \\
\text { weed) }\end{array}$ & 10 & 10 & 10 & 10 & 10 & 50 & 10 \\
\hline $\begin{array}{l}\text { Total } \\
\text { Mean }\end{array}$ & & & & & & & \\
\hline \hline
\end{tabular}

B. Number of Weevils that Survived per Sample, per Treatment after Seven Days

Table II exhibits the number of live rice weevils per sample per treatment after one week. Treatment 1 (control-without dried Siam weed) shows that all (50) rice weevils survived in seven days. Treatment 2 (10\% dried Siam weed) follows with a total of 20 rice weevils, treatment 3 (20\% dried Siam weed) with 14 rice weevils that survived, treatment 4 (30\% dried Siam weed) with 6 rice weevils survived. The least was observed in treatment 5 (40\% dried Siam weed) with 2 rice weevils that survived.

ANOVA single factorial revealed no significant difference in the result obtained. No significant difference exists among treatments with dried Siam weeds, (T2, T3, T4 and T5) and the control. However, in Figure 5 (percentage of mortality) higher mortality was observed as the dried leaves of Siam 
weed increased. The result implied that the use of dried Siam weeds as bedding materials would eradicate the presence of rice weevils in containers in seven days.

There are numerous studies that used the potential of Siam weed as insecticide and can attest to the result obtained. A study on the used of Chromolaena odorata oils were found to be effective against both the larvae and adults of mosquitoes [7]. Another study on the effect of leaf Chromolaena odorata on the egg hatchability, mortality of first and fourth larval instars and pupal mortality of Aedes aegypti was found to be significant [8]. Another similar research on Siam weed extract indicates the usefulness of plant materials in the control of obnoxious mosquito. It also opens additional approach to the management of environment from toxic chemicals that are non-biodegradable and cause environmental imbalance in the ecosystem [9]. C. odorata appreciably protected treated crops against infestation of Pod Sucking Bugs, giving relatively high total grain yield. Thus Siam weed can serve as alternatives to synthetic insecticides for managing Pod Sucking Bugs attack on cowpea [10]. Chromolaena odorata which can be found in Malaysia was examined for insecticidal properties against termites Macrotermes carbonarius and Globertermes sulphureus. The result of the study expresses the essential oil of stem and leaves of $C$. odorata had fumigant toxicities against both species of termites. Both stems and leaves of $C$. odorata essential oil could be used as an alternative protectant for wood and products of wood against termites [11].

TABLE II: NUMBER OF RICE WEEVILS PER SAMPLE, PER TREATMENT THAT SURVIVED AFTER ONE WEEK

\begin{tabular}{lllllllc}
\hline \hline Treatment/sample & 1 & 2 & 3 & 4 & 5 & Total & Mean \\
\hline 1 (control) & 10 & 10 & 10 & 10 & 10 & 50 & 10 \\
\hline $\begin{array}{l}2(10 \% \text { dried Siam } \\
\text { weed) }\end{array}$ & 6 & 0 & 4 & 2 & 8 & 20 & 4 \\
\hline $\begin{array}{l}3(20 \% \text { dried Siam } \\
\text { weed) }\end{array}$ & 0 & 4 & 2 & 2 & 6 & 14 & 2.8 \\
\hline $\begin{array}{l}4(30 \% \text { dried Siam } \\
\text { weed) }\end{array}$ & 0 & 4 & 0 & 2 & 0 & 6 & 1.2 \\
\hline $\begin{array}{l}5(40 \% \text { dried Siam } \\
\text { weed) }\end{array}$ & 2 & 0 & 0 & 0 & 0 & 2 & .4 \\
\hline $\begin{array}{l}\text { Total } \\
\text { Mean }\end{array}$ & & & & & & 92 & \\
\hline \hline
\end{tabular}

\begin{tabular}{|c|c|c|c|c|c|c|}
\hline \multicolumn{7}{|l|}{ ANOVA } \\
\hline $\begin{array}{l}\text { Source of } \\
\text { Variation }\end{array}$ & $S S$ & $d f$ & $M S$ & $F$ & $\begin{array}{c}P \\
\text {-value } \\
\end{array}$ & $\begin{array}{c}F \\
\text { crit }\end{array}$ \\
\hline Between & & & & 0.1 & & \\
\hline Groups & 8.64 & 4 & 2.16 & 2 & 0.97 & 2.87 \\
\hline Within & & & 17.8 & & & \\
\hline Groups & $\begin{array}{l}356.8 \\
365.4\end{array}$ & 20 & 4 & & & \\
\hline Total & 4 & 24 & & & & \\
\hline
\end{tabular}

\section{Percentage of Mortality per Sample, per Treatment after Seven Days}

Table III expresses the mortality rate per treatment. Highest percentage of mortality was observed in treatment $5(40 \%$ dried Siam weeds), followed by those in treatment $4(30 \%$ dried Siam weeds), treatment 3 ((20\% dried Siam weeds) and treatment 2 (10\% dried Siam weeds). Weevils in treatment 1 (control) survived and still live after seven days of observation.

Fig. 5 expresses the mortality rate in graph. The result revealed that as the dried Siam weeds increase in proportion by weight, mortality rate of rice weevils increases. This could be attributed to the phytochemical content of leaves of this plant, which have be found to be a rich source of flavonoids, specifically quercetin, sinensetin, sakuranetin, padmatin, kaempferol, salvagenin [12]. Studies on the effects of higher doses of flavonoids in insects alter normal body functions. The effects of flavonoids on the transhydrogenation, NADH oxidase, and succinate dehydrogenase reactions suggest that compounds of this nature may prove valuable in the control of insect populations by affecting mitochondrial enzyme components. [13] Quercetin dehydrate, rutin hydrate and naringine can be used as botanical insecticides and incorporated into integrated management programs of the aphid. [14].

TABLE III: NUMBER OF RICE WEEVILS PER SAMPLE, PER TREATMENT THAT DIED AFTER ONE WEEK /PERCENTAGE OF MORTALITY

\begin{tabular}{lcccccccc}
\hline \hline Treatment/sample & 1 & 2 & 3 & 4 & 5 & Total & Mean & $\begin{array}{l}\% \text { of } \\
\text { Mortalit) }\end{array}$ \\
\hline 1 (control) & 0 & 0 & 0 & 0 & 0 & 0 & 0 & 0 \\
\hline $\begin{array}{l}\text { 2(10\% dried Siam } \\
\text { weed) }\end{array}$ & 4 & 1 & 6 & 8 & 2 & 30 & 6 & 60 \\
\hline
\end{tabular}

$3(20 \%$ dried Siam

$\begin{array}{lllllllll}\text { weed) } & 1 & 6 & 8 & 8 & 4 & 36 & 7.2 & 72\end{array}$

$4(30 \%$ dried Siam

\begin{tabular}{lllllllll} 
weed) & 1 & 6 & 1 & 8 & 1 & 44 & 8.8 & 88 \\
& 0 & & 0 & & 0 & & & \\
\hline
\end{tabular}

\begin{tabular}{|c|c|c|c|c|c|c|c|c|}
\hline $\begin{array}{l}5(40 \% \text { dried Siam } \\
\text { weed })\end{array}$ & 8 & $\begin{array}{l}1 \\
0\end{array}$ & $\begin{array}{l}1 \\
0\end{array}$ & $\begin{array}{l}1 \\
0\end{array}$ & $\begin{array}{l}1 \\
0\end{array}$ & 48 & 9.6 & 96 \\
\hline Total & & & & & & 158 & & \\
\hline Mean & & & & & & & $\begin{array}{l}31 . \\
6\end{array}$ & \\
\hline
\end{tabular}

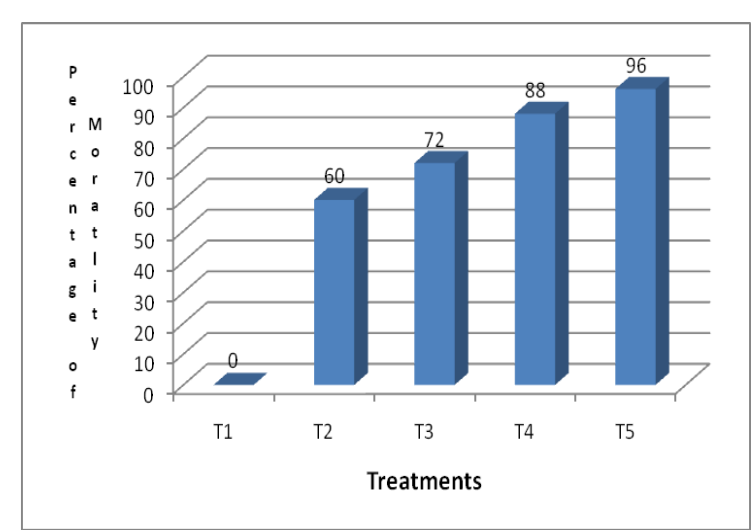

Fig. 5. Percentage of mortality after seven days.

\section{Motility of Live Weevils per Treatment that Survived after Seven Days}

Table IV summarizes the motility of rice weevils after one week of observation. Weevils in the T1 (control) were still 
lively and crawled in the opening of the container (Fig. 6). Those in treatments with dried Siam weeds seems lethargic and moved slow compared with those in the control.

TABLE IV: MotILITY OF LIVE WEEVILS PER TREATMENT AFTER SEVEN DAYS

\begin{tabular}{ll}
\hline \hline treatment & Motility \\
\hline 1 (control) & lively \\
$2(10 \%$ dried Siam weed) & $\begin{array}{l}\text { Lethargic } \\
\text { (slow) }\end{array}$ \\
$3(20 \%$ dried Siam weed) & $\begin{array}{l}\text { Lethargic } \\
\text { (slow) }\end{array}$ \\
$4(30 \%$ dried Siam weed) & $\begin{array}{l}\text { Lethargic } \\
\text { (slow) }\end{array}$ \\
$5(40 \%$ dried Siam weed $)$ & Lethargic \\
& (slow) \\
\hline \hline
\end{tabular}

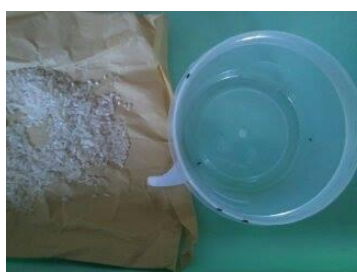

Fig. 6. Sample of live rice weevils in treatment 1(control) after seven days.

\section{CONCLUSION}

The result of this study expressed that the percentage of mortality increases as dried leaves of Siam weed increased. To get rid the rice weevils in the storage areas, rice farmers and rice traders could use dried leaves of Siam weed as bedding materials in their storage area, to maintain the quality of the rice even after it is no longer harvest season. A follow-up study on the use of dried Siam leaves as control on other insects in the storage areas should be done.

\section{ACKNOWLEDGMENT}

The author acknowledges her invaluable Professors from University of the Philippines-Open University, Dr. Ricardo Bagarinao and Prof. Sol Marie Hidalgo. Administrators of the College of Arts and Sciences, San Beda College Manila; Dr. Tessie R. Da Jose-Dean, Dr. Christian Bryan Bustamante Vice-Dean, Dr. Fedeliz S. Tuy, Associate Vice-Dean for their encouragement.

\section{REFERENCES}

[1] B. Drees and J. Jackman, Field Guide to Texas Insects, Houston, Texas, Gulf Publishing Company, 1999, ch. 2.

[2] L. Awanyo, "Dealing with weedy problem in agriculture: the role of three agricultural land use management practices in the Forest-Savanna Ecological Zone of Ghana," Area, vol. 40, no. 4, pp. 446-458, December 2008.

[3] M. Traugott. (January 2014). Journal of Pest Science. [Online]. 85(1). pp. 1-3. Available: http://www.springer.com/life+sciences/ entomology journal/10340

[4] T. Ellis. (December 2013). Plants as protectants against storage pests. Focus on Essential Extracts. [Online]. 1(1). pp. 1-2. Available: http://www.new-ag.info/00-3/focuson/focuson $4 . h t m l$

[5] C. Ikewuchi, O. Ayalogu, and N. Onyeike "Proximate and phytochemical profile of sansevieria liberica gérôme and labroy," Journal of Applied Sciences and Enviromental Management, vol. 14, no. 2, pp. 103-106, June 2010.
[6] L. Codilla and E. Metillo, "Distribution and abundance of the invasive plant species Chromolaena odorata L. in the Zamboanga Peninsula, Philippines," International Journal of Environmental Science and Development, vol. 2, no. 5, pp. 406-410, 2011.

[7] J. Ahiati. (November 2013). A Study of the Insecticidal Effects of Chromolaena Odorata Oil Extracts on the Larvae and Adults of Mosquitoes (Family Culicidae). [Online]. Available: http://esa.confex.com/esa/2004/techprogram/paper_14489.htm

[8] D. Rajmohan and K. Logankumar, "Studies on the insecticidal properties of Chromolaena odorata (Asteraceae) against the life cycle of the mosquito," Journal of Research in Biology, vol. 1, no. 4, pp. 253-257, 2011.

[9] B. M. Matur and B. J. Davou, "Comparative larvicidal properties of leaf extract of Chromolaena odorata L (Composidae) and Chlopyrifos (organophosphorus compound) on Simulium larvae," Journal Biomedical and Environmental Science, vol. 20, no. 4, pp. 313-316, August 2007.

[10] M. Degri, D. Mailafiya, and J. Wabekwa, "Efficacy of aqueous leaf extracts and synthetic insecticide on pod-sucking bugs' infestation of cowpea (Vigna unguiculata L.) Walp in the Guinea Savanna Region of Nigeria," Journal on the Advances in Entomology, vol. 1, no. 2, pp. 10-14, 2013.

[11] F. Abdullah1 et al., "Fumigant Toxicities of Chromolaena odorata against Macrotermes carbonarius and Globertermes sulphureus," research presented at the Symposium of International Study of Chemical Ecology, Australia, July 2013.

[12] N. C. Man, "Phytochemical analysis of the leaves of Chromolaena odorata," International Journal of Scientific and Research Publications, vol. 3, no. 1, pp. 1-2, January 2013.

[13] K. Vandockk, J. Mitchell, and C. Fioravanti, "Effects of plant flavonoids on Manduca sexta (tobacco hornworm) fifth larval instar midgut and fat body mitochondrial transhydrogenase," Archives of Insect Biochemistry and Physiology, vol. 80, no. 1, pp. 15-25, June 2012.

[14] A. Mazen, "Impact of flavonoids against woolly apple aphid, eriosoma lanigerum (hausmann) and its sole parasitoid, aphelinus mali (hald.)," Journal of Agricultural Science, vol. 4, no. 2, 2012.

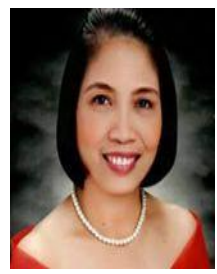

Liwayway H. Acero is a member of Asia Pacific Chemistry, Biology, Environment, Engineering Society, editorial member for Global Science and Technology Forum, member of the following national societies. Philippine Society of Animal Sciences, Biology Teachers Association in the Philippines, Research in Education Training Institute (Philippines), National Organization for Professional Teachers (Philippines), International Training Center on Pig Husbandry (Philippines). She was born in Narra Pala-wan Philippines on February 18, 1966 Educational background: Doctor of Education major in Educational Management from Palawan State University on March 2003. She conducted her dissertation as research student at Okayama University Graduate School of Education in Japan on March to June 2000. She got her diploma in science teaching -major in biology in 2009 from the University of the Philippines-Open University in Los Banos Laguna. She received her master of science degree in agricultural education major in agricultural education minor in Agronomy from the Western Philippines University in Aborlan, Palawan, Philippines on April 1993. She got her bachelor of science degree in Agriculture (cum laude), major in Animal Husbandry and minor in Agronomy from the Western Philippines University in Aborlan, Palawan Philippines on April 1986.

She is an assistant professor and the chairperson of the Department of Natural Sciences, College of Arts \& Science in San Beda College, Mendiola, Manila, Philippines. Prior to her employment in San Beda College in Manila, she had served as professor for 20 years in Western Philippines University in Puerto Princesa City, Palawan, Philippines. She handled several administrative works aside from teaching profession. She served as assistant dean of Western Philippines University, Puerto-Princesa Campus from 2004 to 2006.Director for Instruction 2002-2003. Department Chairperson of the Education Department from 2003-2006. Department chairperson of the Agribusiness Department \&chairperson for the thesis committee from 2000-2003. 